\title{
Active bacterial community structure along vertical redox gradients in Baltic Sea sediment
}

\author{
Anna Edlund ${ }^{1,2}$, Fredrik Hårdeman ${ }^{1,3}$, Janet K. Jansson ${ }^{2,4}$ and Sara Sjöling ${ }^{1^{*}}$ \\ ${ }^{1}$ Södertörn University College, School of Life Sciences, SE-141 89 Huddinge, Sweden \\ ${ }^{2}$ Swedish University of Agricultural Sciences, Department of Microbiology, SE-750 07 Uppsala, \\ Sweden \\ ${ }^{3}$ Department of Laboratory Medicine, Division of Clinical Microbiology, Karolinska Institute, \\ Karolinska University Hospital Huddinge, SE-141 89, Huddinge, Sweden \\ ${ }^{4}$ Ecology Department, Earth Sciences Division, Lawrence Berkeley National Laboratory, MS 70A- \\ 3317, One Cyclotron Rd., Berkeley, 94720 CA, USA.
}

Running title: Active bacteria along redox gradients

*For correspondence: sara.sjoling@sh.se; Tel: (+46)86084767; Fax: (+46)86084510

The two first authors contributed equally to the experimental work.

Key words: vertical sediment profile, redox, bromodeoxyuridine (BrdU), reverse transcription (rt) PCR, terminal-restriction fragment length polymorphism (T-RFLP), Baltic Sea sediment 


\section{Summary}

Community structures of active bacterial populations were investigated along a vertical redox profile in coastal Baltic Sea sediments by terminal-restriction fragment length polymorphism (T-RFLP) and clone library analysis. According to correspondence analysis of T-RFLP results and sequencing of cloned 16S rRNA genes, the microbial community structures at three redox depths $(179 \mathrm{mV},-64 \mathrm{mV}$ and $-337 \mathrm{mV}$ ) differed significantly. The bacterial communities in the community DNA differed from those in bromodeoxyuridine (BrdU)-labeled DNA, indicating that the growing members of the community that incorporated BrdU were not necessarily the most dominant members. The structures of the actively growing bacterial communities were most strongly correlated to organic carbon followed by total nitrogen and redox potentials. Bacterial identification by sequencing of $16 \mathrm{~S}$ rRNA genes from clones of BrdU-labeled DNA and DNA from reverse transcription PCR (rt-PCR) showed that bacterial taxa involved in nitrogen and sulfur cycling were metabolically active along the redox profiles. Several sequences had low similarities to previously detected sequences indicating that novel lineages of bacteria are present in Baltic Sea sediments. Also, a high number of different 16S rRNA gene sequences representing different phyla were detected at all sampling depths.

\section{Introduction}

Marine sediments are vertically stratified habitats as a result of available electron donors and respiration processes (Sørensen et al., 1979; Fenchel and Finlay, 1995). The vertical sequence of electron acceptors roughly follows the order of decreasing

free energy yield. Redox reactions consume oxidants in the order oxygen, nitrate and 
manganese, iron and sulfate (Braker et al., 2001). Therefore, marine sediments are typically characterized by a thin oxic surface layer, an anoxic but oxidized zone, in which nitrate, manganese oxide and iron oxides are the main electron acceptors, and a sulfidic zone, in which sulfate reduction predominates (Fenchel and Finlay, 1995). Several factors determine the quantity, vertical distribution, and chemical composition of the sediments. These factors include primary production, contributions of allochthonous material, adsorption of organic material in mineral phases, water column depth, sedimentation rates, bioperturbation, the concentration of dissolved oxygen and bacterial diversity and activity (Stumm and Morgan, 1981; Cowie and Hedges, 1992; Hedges and Keil, 1995). Although biogeochemical redox stratification has been widely studied in sediments (for example, Canfield et al., 1993; Thamdrup et al., 1994), only limited data are available that correlate microbial community compositions to redox stratification in sediments and soil (Urakawa et al., 2000; PettRidge and Firestone, 2005). In marine sediments, microbial 16S rRNA genes, representative of different phylogenetic groups, and genes encoding different metabolic functions show clear depth variable community trends (Braker et al., 2001; Stach et al., 2003; Mußman et al., 2005; a. Wilms et al., 2006; b. Wilms et al., 2006; c. Wilms et al., 2006). However, it has not been established which genes are representative of metabolically active populations. This information is of particular interest considering that most marine bacteria are thought to have low metabolic activity, until conditions become favorable for growth (Colwell, 2000).

In this study, our aims were to identify metabolically active bacteria in Baltic Sea sediments and to test if their distribution is influenced by redox parameters (i.e. available electron donors and acceptors) along vertical sediment profiles. For this purpose we used two different approaches for studying metabolically active and 
potentially growing bacteria in the sediments; i.e. amplification of 16S rRNA genes from bromodeoxyuridine (BrdU) labeled DNA (Artursson and Jansson, 2003; Urbach et al., 1999; Warnecke et al., 2005) and from cDNA obtained by reverse transcriptase (rt) PCR of RNA (Teske et al., 1996). BrdU is incorporated into the DNA of growing cells as a thymidine analogue and BrdU immunocapture was previously demonstrated as a simple approach for detection of growing (i.e. DNA replicating) bacterial populations in polluted Baltic Sea sediments (Edlund and Jansson, 2006). By contrast, rt-PCR can be used to elucidate which bacteria are actively transcribing $16 \mathrm{~S}$ rRNA genes. Since BrdU immunocapture relies on uptake of BrdU into cells, this could be a limitation of this approach as not all bacteria may be capable of uptake of BrdU, whereas rt-PCR could be limited by the efficacy of the reverse transcription reaction. Therefore, we were interested in using both of these approaches to get more comprehensive information about the identities of the bacteria growing in the sediment layers.

\section{Results}

Total bacterial community structure at different redox depths

Sediment core samples were collected at three locations in a relatively undisturbed region of the Baltic Sea (Fig. 1) and the sediment cores were vertically dissected into fractions according to the following redox states: oxidized $(179 \mathrm{mV})$, intermediate ($64 \mathrm{mV})$ and reduced $(-337 \mathrm{mV})$. Community DNA representing the total bacterial community was extracted from each depth fraction and the bacterial community structures at each redox depth were determined by T-RFLP and correspondence analysis (CA). We chose to use CA for the multivariate statistical analyses because CA did not generate any artifacts in the ordination diagram, by comparison to other 
multivariate statistics approaches, such as Principal Component Analysis. The CA plots indicated that the data had a unimodal frequency distribution and not a linear distribution, which PCA presumes.

The bacterial community profiles were highly reproducible between replicate sediment cores and between sampling stations (Fig. 2a), suggesting that the distribution patterns for the independent replicates taken at the different sites were very similar. Our results confirmed previous studies that have demonstrated that TRFLP is a highly reproducible and robust technique that yields high quality fingerprints consisting of fragments of precise size (Osborn et al., 2000).

In the first $\mathrm{CA}$ ordination analysis, representing total bacterial community DNA, $83 \%$ of the variance observed in the T-RFLP data was explained by environmental factors. Thus the majority of the changes in community structure can be attributed to the in situ conditions determined in this analysis (Fig. 2a). Community profiles from totally extracted DNA and from BrdU-labeled DNA were also analyzed in the same matrix in CA (data not shown). In this analysis none of the community profiles representing the different depths and the DNA extraction methods clustered together. In fact, the T-RFLP profiles of the BrdU-labeled communities were densely clustered together on one side of the CA ordination diagram due to the very large differences in the respective community profiles for total and active bacteria (data not shown). Therefore, we chose to statistically analyze the active and total community profiles separately for better resolution, as described above. These results indicate that the community members representing BrdU-labeled DNA and totally extracted DNA are clearly different (Fig. 2).

Interestingly, the bacterial community architecture was significantly different along the vertical sampling scale (Fig. 2a). However at a given depth community 
structures for the three sampling sites were similar, demonstrating that the bacterial communities were equally distributed horizontally within the sampling area (Fig. 2a).

Community structure of metabolically active bacteria at different redox depths BrdU-immunocapture was used to extract DNA representative of growing bacteria (i.e. those that are actively replicating DNA) in the sediment samples collected at each sampling location and depth and the community structures of the growing bacteria were determined by T-RFLP and CA (Fig. 2b). In CA representing the BrdU-labeled DNA (Fig. 2b) $62 \%$ of the changes in the community composition were represented by the first axis, indicating that some environmental variables influenced the active bacterial community. According to results from the Kolmogrov-Smirinov normality test, the environmental variables and CA coordinates obtained from T-RFLP analysis were normally distributed. Subsequently, regression analysis was performed to determine which environmental variables affected the community (Table 1; Table 2). The actively growing bacterial community profiles were significantly impacted by organic carbon and total nitrogen contents and redox potentials but not by total phosphorous contents or dry weights of the sediments (Table 2).

\section{Identification of growing bacteria at different depths}

16S rRNA genes were cloned and a total of 346 clones were sequenced from the BrdU-labeled DNA and the rt-PCR cDNA to identify the bacteria that were growing and transcribing, respectively, at each redox depth. A total of 83,76 and 82 unique sequences from redox depths $179 \mathrm{mV},-64 \mathrm{mV}$ and $-337 \mathrm{mV}$, respectively, were obtained from the BrdU-immunocaptured DNA. Only one sampling depth (-64 mV) was analyzed by rt-PCR and 61 unique sequences were obtained using that approach. 
Phylogenetic analyses, using both the Greengenes workbench classification tool and Maximum Likelihood analysis, showed that the identities of members of the growing bacterial communities were significantly different at the different redox depths (Fig. 3). Bacterial taxa were assigned according to nomenclature available at http://greengenes.lbl.gov/Download/Taxonomic_Outlines/Comparing_Phyla from 5 Curators v9-14-05.html (DeSantis et al., 2006). Several of the detected sequences were redox specific at the phylogenetic order level and their relative frequencies were as follows: 8 at $179 \mathrm{mV}, 36$ at $-64 \mathrm{mV}$ and 18 at $-337 \mathrm{mV}$ (Fig. 3). By contrast, some orders had representative sequences at all three redox depths. These were in general previously unclassified sequences belonging to Proteobacteria (Alpha-, Beta-, Gamma- and Deltaproteobacteria), Chloroflexi, Planctomycetes, Chlorobi, Actinobacteria, Bacteroidetes, OP8, OP11, and OS-K phyla (Fig. 3). Notably, a large fraction of the sequenced 16S rRNA genes from the different redox depths showed only low sequence similarities (approximately 93\%) to previously deposited sequences in data bases (GenBank) indicating that Baltic Sea sediments harbor a largely unexplored microflora.

Since the 16S rRNA gene sequences and the T-RFLP data were obtained from the same BrdU-labeled and immunocaptured DNA, the results could be directly compared and the information could be used to provide possible identities of metabolically active and growing bacterial populations in the sediment layers. In turn, T-RFLP data could be used to determine the relative abundances of putative species identified by cloning and sequencing. By using the TAP program in the Ribosomal Data Project (RDP) database (Maidak et al., 2000, http://rdp8.cme.msu.edu/html/analyses.html) we putatively identified TRFs that had no corresponding matches among the clones (Table 3). Ninety-three cloned sequences 
could be matched to specific TRFs in T-RFLP profiles from BrdU-labeled DNA when a +/- 1 base pair difference was allowed between the TRF length and the matching in silico restriction site for HhaI (Table 3). Since several of the clone sequences had similar TRF sizes, some TRFs were assigned multiple putative identities (Table 3). In total, 14 TRFs were assigned putative identities by matching to $16 \mathrm{~S}$ rRNA gene clone sequences and 8 TRFs that could not be matched to clones were putatively identified by matching TRF lengths to predicted lengths for $16 \mathrm{~S}$ rRNA gene sequences deposited in the TAP database. Consequently, only two TRFs were not assigned putative identities.

\section{Comparison of rt-PCR and BrdU-immunocapture}

T-RFLP analysis of reverse transcribed rRNA was performed for redox depth $-64 \mathrm{mV}$ and compared to the results obtained with BrdU immunocapture at the same depth. Both approaches resulted in several TRFs of the same size, suggesting that similar bacterial populations were detected by both methods (Table 3 ). These TRFs were putatively identified as belonging to Alpha-, Gamma- and Deltaproteobacteria and Actinobacteria, Acidobacteria, Planctomycetes, Cyanobacteria and Chloroflexi phyla (Table 3). Only 6 of the TRFs representative of actively growing and/or transcribing populations were shared with those detected from directly extracted community DNA, confirming that the majority of the growing bacterial populations were not dominant members of the total community. The number of TRFs was $40 \%$ higher for the rtPCR samples compared to the BrdU-labeled DNA and the majority of these had higher molecular weights (>380 bp) (Table 3).

In the $16 \mathrm{~S}$ rRNA gene clone libraries, 61 putative species representing 13 phyla were detected using rt-PCR, whereas 76 putative species representing 20 phyla were 
detected by BrdU-immunocapture (Fig. 4). The 16S rRNA genes sequences, that were very similar to each other ( $>99 \%$ ) using both the rt-PCR and BrdU-immunocapture approaches were unclassified at the species level but belonged to the C6 order within the Planctomycetes phylum (Fig. 3) and unclassified groups within the Acidobacteria, Verrucomicrobia, Alpha- and Gammaproteobacteria phyla and unclassified proteobacteria (Fig. 3).

\section{Discussion}

According to results from T-RFLP analysis of $16 \mathrm{~S}$ rRNA gene fragments amplified from total DNA extracts and BrdU-labeled DNA, the bacterial communities were significantly different at different redox depths in Baltic Sea sediments. These results are consistent with previous findings where variations in microbial communities were correlated to dramatic changes in redox potentials in coastal sediments and soil (Urakawa et al., 2000; Pett-Ridge and Firestone, 2005). However, since there is a common lack of internal redox equilibrium in natural environments redox potential measurements in general must be interpreted with caution. Thus the captured redox values in this study do not represent absolute values.

The most significant variables for structuring the metabolically active bacterial communities along the vertical gradient in the sediments were organic carbon, total nitrogen content and redox potential, confirming previous studies where these parameters represented key components that determined bacterial activity and diversity in marine sediments (Ravenschlag et al., 2000; Scala and Kerkhof, 2000; Urakawa et al., 2000; Braker et al., 2001; Hunter et al., 2006).

In contrast to the observed changes across a vertical scale, the bacterial communities were similar at a given redox depth, indicating a relatively homogenous 
horizontal spatial distribution within a kilometer area in this region of the Baltic Sea. Similar bacterial community structures were also found across a more narrow sampling distance (i.e. $0.3 \mathrm{~km}$ ) in another region of the Baltic Sea that was highly contaminated with pollutants (Edlund and Jansson, 2006). However, when samples were taken along a $25 \mathrm{~km}$ eutrophication gradient in the Baltic Sea, the bacterial communities varied significantly along the gradient and changes were correlated to changes in environmental parameters (Edlund et al., 2006). Taken together these results suggest that bacterial community structures in Baltic Sea sediments are similar along small horizontal spatial scales if the environmental variables are relatively constant, but these similarities decrease with increasing geographical distances.

We screened 16S rRNA gene sequences from BrdU-labeled DNA and rt-PCR cDNA to determine whether there were bacterial populations that were actively growing and/or transcribing, respectively, at specific redox depths in the sediments. Generally, the bacterial communities varied considerably at the order level while the major phylogenetic groups were similar for all redox depths. Several of the identified sequences clustered within classes and phyla of bacteria that are relatively unknown. Interestingly, several sequences that we abbreviated 'unclassified Baltic Sea sediment' formed separate clusters within the Actinobacteria, Acidobacteria, Betaand Gammaproteobacteria, suggesting that they are unique for Baltic Sea sediments (Fig. 3). However, some sequences clustered within known groups, such as the order Myxococcales belonging to the Deltaproteobacterial class at lower depths. Several members of the Myxососcales order are known iron-, and nitrate reducers (Lonergan et al., 1996; Treude et al., 2003) and these processes may be occurring at the lower redox depths sampled. In addition, several of the sequences that were present at the reduced redox depths were related to members of the ammonia oxidizing and the 
denitrifying Betaproteobacterial families, Nitrosomonadales and Comamonadaceae, respectively (Khan and Hiraishi, 2001). The high sequence identity of Comamonadaceae sequences to known denitrifying bacteria (99\%) suggests that these bacteria correspond to denitrifiers. However, sequences of Nitrosomonadales had low identities to known sequences $(\leq 93 \%)$, and one can only speculate about their potential role in ammonia oxidation and/or denitrification processes.

Several sequences, representative of the Planctomycetes phylum, were also redox specific (e.g. sequences clustering within the groups Planctomycetacia, Anammoxales, C6 and agg27) (Fig. 3). Planctomycetes are known to be ubiquitous in the environment and they catalyze important transformations in global carbon and nitrogen cycles (Glöckner et al., 2003). The class Planctomycetacia was previously reported to possess methanopterin/methanofuran-linked functions indicating that they are involved in the cycling of methane (Chistoserdova et al., 2004) and this process might also be occurring at the reduced depths analyzed in this study. Also, the presence of Anammoxales gives us the first indication of putative active "anammox" bacteria in Baltic Sea sediments suggesting an important link to the nitrogen cycle.

Some unique sequences corresponding to sulfate reducing bacteria were also found for the reduced and oxidized redox depths, respectively. These sequences clustered within the Desulfobacteraceae and Desulfobulbaceae families, belonging to the Deltaproteobacterial class. Their presence in this study indicates that sulfate reduction could be occurring both in the reduced and oxidized sediment depths, but this needs to be confirmed by activity measurements.

For the first time to our knowledge, we used two techniques with different aspects of cell growth to study metabolically active and growing bacteria: 1) analysis of reverse transcribed $16 \mathrm{~S}$ rRNA from total RNA extracts from sediment and 2) 
immunocapture of bromodeoxyuridine labeled DNA from DNA extracts from the same sediment samples. Several populations were detected by both of these approaches, showing a high correlation between detection of metabolically active and growing bacteria based on DNA replication and transcription. However, when analyzing reverse transcribed RNA, Gammaproteobacteria were more dominant compared to the populations that were amplified from BrdU-labeled DNA (Fig. 4). The reason for this discrepancy could be that the two different approaches reflect different intracellular levels of activity (i.e. DNA replication and transcription). Also, rt-PCR is more of a snapshot approach, i.e. the community members that are active at the specific sampling moment are analyzed, whereas BrdU-immunocapture requires a certain incubation time. Therefore, when using the BrdU approach a larger variety of different metabolically active bacteria have the potential to be assessed. The dominance of Gammaproteobacteria in the rt-PCR results may reflect that these community members were more actively transcribing 16S RNA genes than any other bacterial group at this redox depth at the specific time of sampling.

By comparison of T-RFLP electropherograms obtained from directly extracted community DNA with BrdU-labeled DNA and DNA from rt-PCR (Table 3) it was apparent that most of the dominant bacterial populations were not metabolically active in the sediments as also found in a previous study of polluted Baltic Sea sediments (Edlund and Jansson, 2006). The difference could be due to the prevalence of inactive, or dormant, bacteria that is a common physiological state for bacteria in marine sediments (Luna et al., 2002). Therefore, these results suggest that the most dominant bacterial populations are not necessarily those that are metabolically active and growing and thereby contributing functions in the sediments. 
In summary, we found that both the BrdU-immunocapture- and the rt-PCR approaches were suitable tools for studying actively growing bacterial community structures in combination with T-RFLP and statistical ordination tools. Also as in previous studies, 16S rRNA gene sequence information was used to ascertain the identities of individual community members in the T-RFLP profiles (Edlund and Jansson, 2006; Hjort et al., 2007) and we could putatively identify approximately $70 \%$ of the active community members. The actively growing bacterial community composition in Baltic Sea sediment was significantly impacted by redox parameters and also by organic carbon- and nitrogen contents. Also, it is clear that Baltic Sea sediments harbor a largely unexplored bacterial flora containing several community members that are closely related to bacteria involved in ecologically important processes such as nitrogen and sulfur cycling. However, there were also several groups of bacteria belonging to phyla that are relatively unstudied in marine sediments. Therefore, we highlight several groups of bacteria with potentially important ecological roles that would be interesting to investigate further.

\section{Experimental procedures}

\section{Sediment sampling}

Three replicate sediment cores were collected from sampling sites A $\left(58^{\circ} 49^{\prime} \mathrm{N}\right.$ $\left.17^{\circ} 31^{\prime} \mathrm{E}\right), \mathrm{B}\left(58^{\circ} 49^{\prime} \mathrm{N} 17^{\circ} 32^{\prime} \mathrm{E}\right)$, and $\mathrm{C}\left(58^{\circ} 49^{\prime} \mathrm{N} 60^{\circ} 29^{\prime} \mathrm{E}\right)$ in April 2006, as

previously described (Edlund et al., 2006; Hårdeman and Sjöling, 2007). Immediately after sampling, bromodeoxyuridine (BrdU) incubation and total RNA extraction were performed (see method descriptions below). The remaining samples were frozen and stored at $-80^{\circ} \mathrm{C}$ prior to DNA extraction as described below. 


\section{Chemical analysis}

Redox profiles were measured using a Metrohm $691 \mathrm{pH}$ meter (Radiometer Analytical, Villeurbanne, France) with a Metrohm 6.0451.100 redox electrode (Radiometer Analytical). Oxygen concentrations were measured using a WTW Oxi 330 instrument with a CellOx 325 electrode (Nova Analytics, Inglostadt, Germany). Salinity and temperature were measured with a WTW LF 196 instrument (Nova Analytics) using a TetraCon 96 electrode (Nova Analytics). The Department of Soil Sciences at the Swedish University of Agricultural Sciences, Uppsala, Sweden, performed chemical analyses of total carbon-, nitrogen-, and phosphorous concentrations. Total sediment carbon and nitrogen concentrations were determined with a Leco CN-2000 (Leco Instruments GmbH, Krefeld, Germany) using a dry combustion procedure according to manufacturer's instructions. Total sediment phosphorous concentrations were determined with an ICP-AES (Perkins Elmer Optima 3000DV, Applied Biosystems, Foster City, California) according to the manufacturer's instructions.

\section{BrdU-immunocapture and DNA extractions}

DNA extractions were performed from each of the three separate, replicate sediment cores taken from the 3 sampling stations. However, two replicates corresponding to sampling site $\mathrm{A}$ and one replicate corresponding to sampling site $\mathrm{C}$ were excluded from redox depth $-64 \mathrm{mV}$, since redox values within the range of interest could not be determined from these sediment cores. Total DNA was extracted from $0.5 \mathrm{ml}$ sediment samples using a FastDNA $® S P I N \circledast K i t$ (For Soil) following the manufacturer's instructions (Q-BIOgene). 
DNA from metabolically active bacteria (i.e. DNA replicating bacteria) was extracted by employing the BrdU-immunocapture approach (Urbach et al., 1999; Artursson and Jansson, 2003; Edlund and Jansson, 2006). This method relies on incorporation of BrdU as a thymidine analogue into growing cells during DNA replication. $1 \mathrm{ml}$ portions of sediment samples were supplemented with $2 \mathrm{mM} \mathrm{BrdU}$ (Roche, Mannheim, Germany) in $2 \mathrm{ml}$ microcentrifuge tubes and incubated at $1{ }^{\circ} \mathrm{C}$ (the in situ temperature in the sediment at the time of sampling) in the dark for $48 \mathrm{~h}$. Total DNA was extracted using the FastDNA $® S P I N ® K i t$ (For Soil) as described above and DNA that had incorporated BrdU was purified from the total extracted DNA by immunocapture using antibodies against BrdU as previously described (Urbach et al., 1999; Artursson and Jansson, 2003; Edlund and Jansson, 2006). The BrdU-immunocaptured DNA was washed using a QIAamp® DNA Micro Kit (QIAGEN, Hilden, Germany) according to the manufacturers instructions, prior to PCR amplification.

The efficacy of BrdU-immunocapture was confirmed by comparing visible bands on agarose gels after DNA extraction, immunocapture and PCR amplification with control sediment samples to which no BrdU was added. No PCR amplified product was visible in the controls without BrdU demonstrating that the extraction was successful.

\section{RNA extraction and Reverse-Transcription-PCR}

Total RNA was extracted from $200 \mathrm{mg}$ sediment samples from the $-64 \mathrm{mV}$ redox depth using the FastRNA Pro soil-Direct kit (Q-BIOgene) according to the manufacturer's instructions. The RNA concentration was determined with a Nanodrop ND-1000 spectrophotometer (ND technologies, Wilmington, Delaware USA) and 200 
ng of total RNA were treated with 15 units of DNAse I (Fermentas GMBH, St.LeonRot, Germany) according to the manufacturer's recommendations. Extracted RNA was stored at $-80^{\circ} \mathrm{C}$ until $\mathrm{rt}-\mathrm{PCR}$ was performed.

Superscript II RT-polymerase (Invitrogen Ltd, Paisley, UK) was used in the reverse transcriptase PCR (rt-PCR), according to the manufacturer's recommendations with the universal bacterial reverse primer 926r ( $\left.5^{\prime}-3^{\prime}\right)$ CCGTCAATTCCTTTRAGTTT (Muyzer et al., 1995), to produce complementary DNA to $16 \mathrm{~S}$ rRNA (16S cDNA). DNAse treated RNA was denatured at $65{ }^{\circ} \mathrm{C}$ for 5 min with $200 \mu \mathrm{M}$ dNTP mix (Fermentas) and 25 pmol primer followed by 5 min incubation at $4^{\circ} \mathrm{C}$. First-Strand buffer $(250 \mathrm{mM}$ Tris, $37.5 \mathrm{mM} \mathrm{KCl}$ and $1.5 \mathrm{mM}$ $\mathrm{MgCl}_{2}$; Invitrogen), Dithiothreitol $5 \mathrm{mM}$ and RNAse-inhibitor 20 units (Fermentas), were added. The reaction was equilibrated at $42{ }^{\circ} \mathrm{C}$ for $2 \mathrm{~min}$ before addition of 200 units of Superscript II RT-polymerase followed by $50 \mathrm{~min}$ incubation at $42^{\circ} \mathrm{C}$. Control reactions without RT polymerase were performed to exclude any DNA contamination in the rt-PCR reaction and were evaluated in the 16S rRNA gene amplification steps that followed, see below. All materials that were used to handle RNA were sterilized by autoclaving and baked at $120{ }^{\circ} \mathrm{C}$ for $4 \mathrm{~h}$ before use. Water treated with diethylpyrocarbonate (Q-BIOgene) and RNAse free enzyme kits were used in all steps.

\section{T-RFLP}

Partial 16S rRNA gene sequences (approximately $900 \mathrm{bp}$ ) were amplified from the sediment DNA using the following bacterial primers: fD1-Hex (AGAGTTTGATCMTGGCTCAG) (Weisburg et al., 1991) labeled at the 5'-end with hexachlorofluorescein, and 926r (CCGTCAATTCCTTTRAGTTT) (Muyzer et al., 
1995). Each $50 \mu 1$ polymerase chain reaction (PCR) contained 35 pmol of each primer, 2.5 U of Taq-polymerase (Amersham Bioscience, NJ), PCR buffer, $10 \mathrm{nmol}$ dNTPs and $1 \mu 1$ of 10 - to 100-fold diluted template DNA. Cycling programs were performed using a GeneAmp PCR System 2400 thermocycler (Applied Biosystems, Foster City, CA) as follows for bacteria: $5 \mathrm{~min}$ at $95^{\circ} \mathrm{C}$ followed by 30 cycles of $40 \mathrm{~s}$ at $94^{\circ} \mathrm{C}, 1 \mathrm{~min}$ at $56^{\circ} \mathrm{C}, 1 \mathrm{~min}$ at $72^{\circ} \mathrm{C}$ and extension at $72^{\circ} \mathrm{C}$ for $7 \mathrm{~min}$. The PCR products (12 $\mu 1$, approximately 20 ng DNA) were digested for $2 \mathrm{~h}(50 \mu \mathrm{l}$ total volume) using HhaI restriction enzyme (Promega) and the fragments were separated by electrophoresis as described in Hjort et al. (2007). The lengths of the fluorescent terminal restriction fragments (TRFs) were determined by using GeneScan, version 3.1, analysis software (Applied Biosystems), and their relative peak areas were determined by dividing the individual TRFs with the total peak area of peaks within the thresholds of 60 to $500 \mathrm{bp}$. Only peaks with relative fluorescence intensities over $50 \mathrm{U}$ and that contributed to the total community abundance at $1 \%$ or more were

included in the analysis. After excluding the peaks that contributed to less than $1 \%$ of the total community abundance the remaining peaks were re-calculated and included in the remaining analyses.

\section{Cloning}

16S rRNA gene PCR products (approximately $900 \mathrm{bp}$ ) were generated with a proofreading Taq-polymerase (Pfu DNA polymerase, Fermentas), using conditions and thermocycling parameters as described above. Since the T-RFLP results showed that there was minimal variation between the samples (Fig. 2), PCR products from each redox depth were pooled before cloning. This resulted in three 16S rRNA gene pools for BrdU-labeled DNA representing the different redox depths; $179 \mathrm{mV},-64$ 
$\mathrm{mV}$ and $-337 \mathrm{mV}$ and one gene pool for 16S cDNA, representing redox depth -64 mV. PCR products were purified using a QIAquick PCR Purification Kit (Qiagen). An A-overhang was generated by using Taq DNA polymerase (Fermentas) and dATP (Fermentas), followed by purification (QIAquick), prior to cloning (Diaz-Torres et al, 2003). Between 140-180 ng of PCR amplified DNA were cloned into the pCR-2.1 TOPO vector and transformed into E. coli TOP10 (TOPO-TA cloning kit, Invitrogen) according to the manufacturers recommendations.

\section{Sequencing and phylogenetic analysis}

Cloned 16S rRNA gene fragments were amplified from approximately 100 randomly selected clones from each library, using a standard PCR reaction according to manufacturer's instructions (Invitrogen), with $57{ }^{\circ} \mathrm{C}$ annealing temperature and vector specific primers, m13 forward and m13 reverse. Amplified PCR products were purified using ExoSAP-IT (USB Europe GmbH, Straufen, Germany) according to the manufacturer's recommendations and sequenced from both ends using m13 forward and m13 reverse primers on a 96-capillary ABI3730XL DNA Analyzer (Applied Biosystems) by Macrogen (Macrogen Inc, Seoul, Korea).

The sequences were assembled using SEQMAN II (Dnastar Inc, Madison, WI, USA), analyzed (http://greengenes.lbl.gov/cgi-bin/nph-index.cgi) (DeSantis, 2006) aligned by NAST and checked for chimeras using Bellerophon3 (greengenes, http://greengenes.lbl.gov/cgi-bin/nph-bel3_interface.cgi). Chimeric sequences, identical sequences within the same depth and poorly aligned sequences were not included in further analyses. Closest relatives in the Greengenes dataset were included in the phylogenetic analysis to determine phylogenetic affiliation of sequenced clones. Unrooted phylogenetic trees were constructed by using the maximum likelihood 
method (Felsenstein, 1981) with the software PHYML version 2.4 (Guindon et al., 2005). One thousand bootstrapped replicate resampling data sets were analyzed. The trees were visualised with the program MEGA 3.1 (http://www.megasoftware.net/) (Kumar, 2004). All sequenced clones (approximately 300) were analyzed with the Mega BLAST program (Zhang et al., 2000) (available at http://www.ncbi.nlm.nih.gov/blast/) for matching 16S rRNA gene sequences. Bacterial taxa were named according to Hugenholtz nomenclature, available at http://greengenes.lbl.gov/Download/Taxonomic_Outlines/Comparing_Phyla_from_5_ Curators_v9-14-05.html.

Putative identification of TRFS

Clones from BrdU labeled DNA and from reverse transcribed DNA were matched to specific TRFs in T-RFLP profiles by performing in silico restriction digestion using the restriction site for the restriction endonuclease HhaI. TRFs that had no corresponding match among the clones were putatively identified by using the TAP program in the Ribosomal Data Project (RDP) database (Maidak et al., 2000, http://rdp8.cme.msu.edu/html/analyses.html).

\section{Statistical analyses}

Statistical analyses were performed on the T-RFLP data resulting from three DNA extractions, from each of three sediment cores taken at each sampling site as described in Edlund et al. (2006). The data were analyzed by Correspondence Analysis (CA) and Principal Component Analysis (PCA) using the multivariate analysis software ADE-4 (http://pbil.univ-lyon1.fr/ADE-4). Initially the data was analyzed with Principal Component Analysis that assumes a linear species response 
curve (i.e. a linear frequency distribution of TRFs). However the data was clearly not linearly distributed since it showed obvious "horseshoe" formations (MüllerSchneider, 1994). Therefore, data was analyzed by CA that assumes a unimodal species response curve (Legendre and Legendre, 1998). Homogeneity of variance for coordinates representing the $1^{\text {st }}$ ordination axis in CA obtained from T-RFLP analysis of BrdU-labeled 16S rRNA genes and environmental variables were tested in a Kolmogrov Smirinov normality test by using Prism 4 software (GraphPad software Inc. San Diego, CA). The $1^{\text {st }}$ ordination axis was of specific interest since it explained the majority of the observed variation within the data set according to CA (Eigenvalue: 62\%). Since CA residuals were normally distributed, linear regression analysis was applied to correlate environmental variables and CA by using Prism 4 software (GraphPad software Inc.). P-, $\mathrm{r}^{2}$-values and the slope of the best-fit line were extracted to present significant relationships.

Nucleotide sequence accession numbers.

These sequence data have been submitted to GenBank under accession numbers EF459825 to EF460126.

\section{Acknowledgements}

We thank Dr. E. Gorokhova at Stockholm University and Dr. M. Lönn at Södertörn University College, Sweden for help with the statistical analyses, Dr A. Poole at Stockholm University, Dr. S. Hallin at the Swedish Agricultural University, Uppsala, Sweden and Dr. G. Jurgens at Helsinki University, Finland for valuable discussions and Dr. Anne Stockenberg, STFI-Packforsk AB, Stockholm, Sweden for access to field equipment. The study was funded by the Baltic Sea Foundation, the Wenner- 
Gren Foundation, the Carl-Tryggers Foundation, the Helge Ax:son Johnson foundation, the Stockholm Marine Research Institute, and in part by U. S. Department of Energy Contract DE-AC02-05CH11231 with Lawrence Berkeley National Laboratory.

\section{References}

Artursson, V. and Jansson, J.K. (2003) Use of bromodeoxyuridine immunocapture to identify bacteria associated with arbuscular mycorrhizal hyphae. Appl Environ Microbiol 69: 6208-6215.

Braker, G., Ayala-del-Rio, H.L. Devol, A.H. Fesefeldt, A., and Tiedje, J.M (2001) Community structure of Denitrifiers, Bacteria, and Arhcaea along redox gradients in Pacific Northwest Marine sediments by Terminal Restriction Fragment Length Polymorphism analysis of amplified nitrite reductase (nirS) and 16S rRNA genes. Appl Environ Microbiol 67: 1893-1901.

Canfield, D. E., Jørgensen, B.B., Fossing, H., Glud, R., Gundersen, J., Ramsing, N.B., Thamdrup, B., Hansen, J.W., Nielsen, L.P., and Hall, P.O.J. (1993) Pathways of organic carbon oxidation in three continental margin sediments. Mar Geol 113: $27-$ 40.

Chistoserdova, L., Jenkins, C., Kalyuzhnaya, M.G., Marx, C.J., Lapidus, A., Vorholt, J.A., Staley, J.T., and Lidstrom, M. E. (2004) The enigmatic Planctomycetes may hold a key to the origins of methanogenesis and methylotrophy. Mol Biol Evol 21: 1234-1241.

Colwell, R.R. (2000) Bacterial death revisited. In Nonculturable microorganisms in the environment. Colwell, R.R., and Grimes, D.J. (eds) Washnigton DC: ASM, pp 325-342. 
Cowie, G.L., and Hedges, J.I. (1992) Sources and reactivities of amino acids in a coastal marine environment. Limnol Ocean 37: 703-724.

DeLong, E.F., Preston, C.M., Mincer, T., Rich, V., Hallam, S.J., Frigaard, N.U., Martinez, A., Sullivan, M.B., Edwards, R., Rodriguez Brito, B., Chisholm S.W., and Karl, D.M. (2006) Community genomics among stratified microbial assemblages in the ocean's interior. Science 311: 496-503.

DeSantis, T.Z., Hugenholtz, P., Larsen, N., Rojas, M., Brodie, E.L., Keller, K., Huber, T., Dalevi, D., Hu, P., and Andersen, G.L. (2006) Greengenes, a Chimera-Checked 16S rRNA Gene Database and Workbench Compatible with ARB. Appl Environ Microbiol 72: 5069-72.

Diaz-Torres, M.L., McNab, R., Spratt D.A., Villedieu A., Hunt N., Wilson M., and Mullany, P. (2003) Novel tetracycline resistance determinant from the oral metagenome. Antimicrob Agents Chemother 47: 1430-1432.

Edlund, A., Soule, T., Sjöling, S., and Jansson, J.K. (2006) Microbial community structure in polluted Baltic Sea sediments. Environ Microbiol 8: 223-232.

Edlund, A., and Jansson, J.K. (2006) Changes in active bacterial communities before and after dredging of highly polluted Baltic Sea sediments. Appl Environ Microbiol 72: $6800-6807$.

Elmgren, R. (1989) Mans impact on the ecosystem of the Baltic Sea - energy flows today and at the turn of the century. Ambio 18: $326-332$.

Felsenstein, J. (1981) Evolutionary trees from DNA sequences: a maximum likelihood approach. Journ Mol Evol 17: 368-376.

Fenchel, T. and Finlay, B.J. (1995) Anaerobic environments. In Ecology and evolution in anoxic worlds. May, R. M. and Harvey, P. H. (eds). Oxford University Press, Oxford. pp 27-28. 
Glöckner, F.O., Kube, M., Bauer, M., Teeling, H., Lombardot, T., Ludwig, W., Gade, D., Beck, A., Borzym, K., Heitmann, K., Rabus, R., Schlesner, H., Amann, R., and Reinhartd, R. (2003) Complete genome sequence of the marine planctomycete Pirellula sp. strain 1. PNAS 100: 8298-8303.

Guindon, S., Lethiec, F., Duroux, P., and Gascuel, O. (2005) PHYML Online-a web server for fast maximum likelihood-based phylogenetic inference. Nucl Acids Res 33: 557-559.

Hedges, J.I., and Keil, R.G. (1995) Sedimentary organic matter preservation: an assessment and speculative synthesis. Mar Chem 49: 81-115.

Hjort. K., Lembke, A., Speksnijder, A., Smalla, K., \& Jansson, J.K. (2007) Community structure of actively growing bacterial populations in plant pathogen suppressive soil. Microb Ecol 53:399-413.

Hunter, E.M., Mills, H.J., and Kostka, J.E. (2006). Microbial community diversity associated with carbon and nitrogen cycling in permeable shelf sediments. Appl Environ Microbiol 72: 5689-701.

Hårdeman, F., and Sjöling, S. (2007) Metagenomic approach for the isolation of a novel low-temperature-active lipase from uncultured bacteria of marine sediment. FEMS Microbiol Ecol 59: 524-534.

Khan, S.T., and A. Hiraishi. (2001) Isolation and characterization of a new poly (3hydroxybutyrate)-degrading, denitrifying bacterium from activated sludge. FEMS Microbiol Lett 205: 253-257.

Kumar, S. Tamura, K., and Nei, M. (2004) MEGA3: Integrated Software for Molecular Evolutionary Genetics Analysis and Sequence Alignment. Brief Bioinformatics 5:150-163. 
Legendre, P., and Legendre, L. (1998) Canonical analysis. In Numerical Ecology. 2nd ed. Legendre, P. and Legendre, L. (eds.). Amsterdam: Elsevier Science BV. pp. $575-633$.

Lonergan, D.J., Jenter, H., Coates, J.D., Schmidt, T., and Lovley, D.R. (1996) Phylogenetic analysis of dissimilatory Fe(III)-reducing bacteria. J Bacteriol 178: $2402-2408$.

Luna, G., Manini, M.E., and Daanovaro. R. (2002) Large fraction of dead and inactive bacteria in coastal marine sediments: comparison of protocols for determination and ecological significance. Appl Environ Microbiol 68: 3509-3513.

Maidak, B.L, Cole, J.R., Lilburn, T.G., Parker, Jr., C.T., Saxman, P.R., Stredwick, J.M., Garrity, G.M., Li, B., Olsen, G.J., Pramanik, S., Schmidt, T.M., and Tidje, J.M. (2000) The RDP (Ribosomal Database Project) continues. Nucl Acids Res 28: $173-374$

Muyzer, G., Teske, A., Wirsen, C.O., and Jannasch, H.W. (1995) Phylogenetic relationship of Thiomicrospira species and their identification in deep-sea hydrothermal vent samples by denaturing gradient gel electrophoresis of $16 \mathrm{~S}$ rDNA fragments. Arch Microbiol 164: 162-172.

Müller-Schneider, T. (1994) The Visualization of Structural Change by Means of Correspondence Analysis. In Correspondence Analysis in the Social Sciences. Greenacre, M., and Blasius, J. (eds). London: Academic Press. pp. 267-279.

Osborn, A.M, Moore, E.R.B., and Timmis, K.N. (2000) An evaluation of terminalrestriction length polymorphism (T-RFLP) analysis for the study of microbial community structure and dynamics. Environ Microbiol 2: 39-50.

Pett-Ridge, J., Firestone, M.K. (2005) Redox fluctuation structures microbial communities in a wet tropical soil. Appl Environ Microbiol 71: 6998-7007. 
Ratering, S., and Schnell, S. (2001) Nitrate-dependent iron(II) oxidation in paddy soil Environ Microbiol 3: 100-109.

Ravenschlag, K., Sahm, K., Knoblauch, K., Jørgensen, B.B., and Amann, R. (2000)

Community structure, cellular rRNA content, and activity of sulfate-reducing bacteria in marine Arctic sediments. Appl Environ Microbiol 66: 3592-3602.

Scala, D.J., and Kerkhof, L.J. (2000) Horizontal heterogeneity of denitrifying bacterial communities in marine sediments by terminal restriction fragment length polymorphism analysis. Appl Environ Microbiol 66:1980-1986.

Stumm, W., and Morgan, J.J. (1981) Aquatic Chemistry: An Introduction Emphasizing Chemical Equilibra. In Natural Waters. Stumm, W. and Morgan, J.J. (eds). John Wiley \& Sons, NY, 780 pp.

Stach, J.E.M, Maldonado, L.A., Masson, D.G., Ward, A.C., Goodfellow, M., and Bull, A.T. (2003) Statistical approaches to estimating bacterial diversity in marine sediments. Environ Microbiol 69: 6189-6200.

Sørensen, J., Jørgensen, B.B., and Revsbech, N.P. (1979) A comparison of oxygen, nitrate, and sulfate respiration in coastal marine sediments. Microb Ecol 5: 105115.

Thamdrup, B., Fossing, H., and Jørgensen, B.B. (1994) Manganse, iron, and sulfur cycling in a coastal marine sediment, Aarhus Bay, Denmark.

Geochim Cosmochim Microbiol 58: 5115-5129.

Teske, A., C. Wawer, G. Muyzer, and Ramsing, N.B. (1996) Distribution of sulfatereducing bacteria in a stratified fjord (Mariager fjord, Denmark) as evaluated by most-probable number counts and denaturing gradient gel electrophoresis of PCRamplified ribosomal DNA fragments. Appl Environ Microbiol 62: 1405-1415. 
Thioulouse, J., Chessel, D., Dolédec, S., and Olivier. J.M. (1997) ADE-4: a multivariate analysis and graphical display software. Stat Comput 7: 75-83.

Treude, N., Rosencrantz, D., Liesack, W., and Schnell, S. (2003) Strain FAc12, a dissimilatory iron-reducing member of the Anaeromyxobacter subgroup of Myxococcales. FEMS Microbiol Ecol 44: 261-269.

Urakawa, H., Yoshida, T., Nishimura, M., and Ohwada, K. (2000) Characterization of depth-related population variation in microbial communities of coastal marine sediment using 16S rDNA-based approaches and quinon profiling. Environ Microbiol 2: 542-554.

Urbach, E., Vergin, L.L., and Giovannoni, S.J. (1999) Immunochemical detection and isolation of DNA from metabolically active bacteria. Appl Environ Microbiol 65: 1207-1213.

Warnecke, F., Sommaruga, R., Sekar, R., Hofer, J.S., and Pernthaler, J. (2005) Abundance, identity, and growth state of Actinobacteria in mountain lakes of different UV transparency. 71: 5551-5559.

Weisburg, W.G., Barns, S.M., Pelletier, D.A., and Lane, D.J. (1991) 16S Ribosomal DNA amplification for phylogenetic study. J Bacteriol 173: 697-703.

Wilms, R., Sass, H., Köpke, B., Köster, J., Cypionaka, H., and Engelen, B. (2006a) Specific bacterial, archaeal, and eukaryotic communities in tidal-flat sediments along a vertical profile of several meters. Appl Environ Microbiol 72: 2756-2764.

Wilms, R., Köpke, B., Sass, H., Chang, T.S., Cypionaka, H., and Engelen, B. (2006b) Deep biosphere-related bacteria within the subsurface of tidal flat sediments. Environ Microbiol 8: 709-719.

Wilms, R., Köpke, B., and Sass, H. (2006c) Methane and sulfate profiles within the subsurface of a tidal flat are reflected by the distribution of sulfate-reducing 
bacteria and methanogenic archaea. FEMS 59: 611-621.

Zhang, Z., Schwartz, S., Wagner, L., and Miller, W. (2000) A greedy algorithm for aligning DNA sequences. Journ Comput Biol 7: 203-14. 
Fig. 1. Study sites: samples were collected from different redox depths from sediment cores sampled in April 2006 at three coastal areas of the Baltic Sea. Sampling locations in the Askö area of the Stockholm archipelago: A $\left(58^{\circ} 49^{\prime} \mathrm{N} 17^{\circ} 31^{\prime} \mathrm{E}\right)$, B $\left(58^{\circ} 49^{\prime} \mathrm{N} 17^{\circ} 32^{\prime} \mathrm{E}\right), \mathrm{C}\left(58^{\circ} 49^{\prime} \mathrm{N} 60^{\circ} 29^{\prime} \mathrm{E}\right)$.

Fig. 2. Ordination diagrams from correspondence analysis (CA) of 16S rRNA genes amplified from totally extracted DNA (a) and from BrdU-labeled DNA (b) from TRFLP analysis of vertical sediment profiles of replicate sediments cores collected at three different sampling stations, A, B and C in Askö area (Fig. 1). Three replicate samples per site were analyzed for redox depths $179 \mathrm{mV}$ and $-337 \mathrm{mV}$. Six replicate samples were analyzed from redox depth $-64 \mathrm{mV}$. Eigenvalues for first- and second ordination axes for total DNA extracts and for BrdU-labeled DNA were $83 \%$ and $2 \%$ and $62 \%$ and $2 \%$, respectively.

Fig. 3. Unrooted16S rRNA gene trees based on maximum likelihood analyses representing sequences belonging to A) Gamma-, Alpha-, Beta- and Epsilonproteobacteria, B) Deltaproteobacteria, WS3, SBR1093, Nitrospirae, Firmicutes, Caldithrix_KSB1, TM6, Cyanobacteria and Gemmatimonadetes, C) Actinobacteria, OD2, OP11, Chloroflexi and Chlorobi, D) Acidobacteria, OS-K, OP8, Bacteroidetes, Verrucomicrobia, OP3 and Planctomycetes from BrdU at redox depths $179 \mathrm{mV}$ (blue); -64 mV (red); $-337 \mathrm{mV}$ (green); from rt-PCR at redox depth -64 mV (turquoise). Reference sequences (black) are indicated by their Greengenes identity numbers. Sequence numbers are followed by their respective accession numbers in GenBank. The nomenclature suggested by Hugenholtz (DeSantis et al., 2006) was used for taxonomy. One thousand bootstrapped replicate resampling data sets were 
analyzed and the scale bar represents $10 \%$ sequence divergence. Bootstrap values below 500 are not shown.

Fig. 4. Bacterial phyla at the different redox depths according to clone analysis of $16 \mathrm{~S}$ rRNA gene sequences from different depths using BrdU-labeled DNA (BrdU -64 mV; $179 \mathrm{mV} ;-337 \mathrm{mV})$ and cDNA from rt-PCR of RNA (-64 mV). 
Table 1. Environmental parameters at sampling stations A, B and C.

\begin{tabular}{|c|c|c|c|}
\hline & Site A & Site B & Site C \\
\hline Redox (mV) & $179 ;-63 ;-339$ & $178 ;-78 ;-332$ & $180 ;-50 ;-341$ \\
\hline $\mathrm{O}_{2}(\mathrm{mg} / \mathrm{l})$ & 9.8; nd; nd & 9.8; nd; nd & 9.7; nd; nd \\
\hline Temperature $\left({ }^{\circ} \mathrm{C}\right)$ & $1.6 ; \mathrm{nd} ; \mathrm{nd}$ & 1.6; nd; nd & $1.5 ; \mathrm{nd} ; \mathrm{nd}$ \\
\hline Salinity (PSU) & $6.7 ;$ nd; nd & 6.6; nd; nd & 6.6 ; nd; nd \\
\hline Dry weight (\%) & $15.3 ; 25.0 ; 27.6$ & $16.5 ; 22.4 ; 27.1$ & $16.2 ; 22.7 ; 27.0$ \\
\hline Organic C $(\%)$ & $4.6 ; 4.4 ; 3.9$ & $4.7 ; 4.7 ; 4.0$ & $4.7 ; 4.8 ; 3.9$ \\
\hline Tot N (\%) & $0.6 ; 0.6 ; 0.5$ & $0.6 ; 0.6 ; 0.5$ & $0.6 ; 0.6 ; 0.5$ \\
\hline Tot $\mathrm{P}(\%)$ & $0.2 ; 0.1 ; 0.1$ & $0.2 ; 0.1 ; 0.1$ & $0.2 ; 0.1 ; 0.1$ \\
\hline
\end{tabular}

Stdv. Redox potential \pm 3 to $15 \mathrm{mV}$.

Total Nitrogen, Total Phosphorus and Organic Carbon are presented in percentage per gram dry weight of sediment.

Stdv. Temp; Sal; N; P; Org. C, \pm 0.1 to 0.3 .

nd indicates not determined.

Dry weight is presented as percentage of dry/wet sediment ratio. Stdv. 0.1 to $4.0 \%$. 
Table 2. Linear regression analysis between environmental variables and 16S rRNA gene distribution and abundances for metabolically active communities along vertical redox gradients in sediments from the Baltic Sea.

\begin{tabular}{llll}
\hline & Slope of & Slope of significantly & $\mathrm{r}^{2}$ \\
& Best-fit line & non zero, P value & value \\
& & & \\
\hline Redox & 222 & 0.0002 & 0.55 \\
DW & 0.35 & n.s & 0.35 \\
Organic C & -4.07 & $<0.0001$ & 0.78 \\
Tot $\mathrm{N}$ & 0.06 & 0.0001 & 0.56 \\
Tot P & 0.01 & n.s. & 0.18 \\
\hline
\end{tabular}

Slope of Best-fit line values and Slope of significantly non zero, $\mathrm{P}$ values, resulting from linear regression analysis of environmental variables (Table 1) and coordinates representing the $1^{\text {st }}$ ordination axis in correspondence analysis of BrdU-labeled 16S rRNA gene profiles (Fig. 2b).

$\mathrm{r}^{2}$ values, linear correlation values resulting from linear regression analysis.

n.s, not significant, $\mathrm{p} \geq 0.005$. 
Table 3. Putative identification of terminal restriction fragments (TRFs) from the intermediate redox depth of $-64 \mathrm{mV}$. Relative abundances of individual TRFs are presented as percentage values for 16S rRNA gene fragments amplified from BrdUlabeled DNA and cDNA from reverse transcribed RNA. TRFs were identified by matching in silico restriction (HhaI) digested sequences from cloned 16S rRNA gene sequences (S) or by using the TAP database

(http://rdp8.cme.msu.edu/html/analyses.html). TRFs that were detected using both rtPCR and BrdU-immunocapture are indicated with asterisks.

\begin{tabular}{|c|c|c|c|c|}
\hline $\begin{array}{l}\text { TRF } \\
\text { Size } \\
\text { (bp) }\end{array}$ & $\begin{array}{l}\text { BrdU } \\
(\%)\end{array}$ & $\begin{array}{c}\text { rt-PCR } \\
(\%)\end{array}$ & $\begin{array}{l}\text { BrdU } \\
\text { and } \\
\text { rt-PCR }\end{array}$ & Identification \\
\hline 61 & 3.8 & 5.8 & $*$ & Proteobacteria, Planctomycetes (S) \\
\hline 64 & 1.9 & 1.8 & $*$ & Firmicutes (TAP) \\
\hline $75^{\mathrm{a}}$ & 6.1 & 1.3 & $*$ & Proteobacteria (TAP) \\
\hline $79^{\mathrm{a}}$ & 1.7 & - & & Proteobacteria (S) \\
\hline $92^{\mathrm{a}}$ & 11.8 & - & & Proteobacteria (S) \\
\hline 94 & - & 3.0 & & Bacteroidetes, Chlorobium (S) \\
\hline 97 & - & 3.1 & & Proteobacteria (S) \\
\hline $100^{\mathrm{a}}$ & 5.7 & 3.0 & $*$ & Proteobacteria $(\mathrm{S})$ \\
\hline $170^{\mathrm{a}}$ & 1.8 & - & & Proteobacteria (TAP) \\
\hline 173 & 1.8 & - & & Proteobacteria (TAP) \\
\hline $205^{\mathrm{a}}$ & - & 1.1 & & Proteobacteria (S) \\
\hline 209 & 5.3 & 3.3 & * & Chloroflexi (S) \\
\hline 211 & 7.7 & 1.8 & * & Proteobacteria, Chloroflexi (S) \\
\hline 215 & 7.2 & 5.7 & $*$ & Chloroflexi (S) \\
\hline 220 & 1.0 & - & & Firmicutes (TAP) \\
\hline
\end{tabular}




\begin{tabular}{|c|c|c|c|c|}
\hline 225 & 6.3 & - & & Proteobacteria, Caldithrix (TAP) \\
\hline 228 & 4.2 & - & & Cyanobacteria (TAP) \\
\hline 312 & 2.1 & 2.3 & $*$ & - \\
\hline 319 & - & 2.5 & & Actinobacteria (TAP) \\
\hline 325 & - & 1.1 & & Proteobacteria (TAP) \\
\hline 338 & - & 10.0 & & Cyanobacteria (S) \\
\hline 341 & 1.7 & 0.8 & $*$ & Proteobacteria (TAP) \\
\hline 352 & 2.0 & 0.9 & $*$ & Proteobacteria (S) \\
\hline 354 & 2.9 & 1.0 & $*$ & TM6, Acidobacteria, Proteobacteria (S) \\
\hline 362 & 2.3 & 2.7 & $*$ & Chloroflexi (S) \\
\hline 366 & 3.5 & 2.3 & $*$ & Proteobacteria (S) \\
\hline 369 & 2.1 & 1.8 & $*$ & Planctomycetes (S) \\
\hline 371 & 1.0 & 1.6 & $*$ & - \\
\hline 374 & 2.3 & 0.5 & $*$ & Actinobacteria, Acidobacteria (S) \\
\hline 376 & - & 8.4 & & Chloroflexi, OS-K, Caldithrix (S) \\
\hline 380 & 5.5 & 1.8 & $*$ & Actinobacteria (S) \\
\hline 416 & - & 3.8 & & Chloroflexi (S) \\
\hline 429 & - & 5.0 & & - \\
\hline 438 & - & 1.7 & & - \\
\hline 445 & - & 1.6 & & Actinobacteria (TAP) \\
\hline 450 & - & 3.7 & & - \\
\hline 459 & - & 1.5 & & Firmicutes (TAP) \\
\hline 466 & - & 2.1 & & - \\
\hline 469 & - & 0.3 & & - \\
\hline 472 & - & 2.2 & & Firmicutes (TAP) \\
\hline 479 & - & 0.9 & & - \\
\hline 487 & - & 2.3 & & - \\
\hline 489 & - & 0.4 & & - \\
\hline 499 & - & 3.0 & & - \\
\hline
\end{tabular}


a. TRF also present in profiles from total DNA extracts.

-, no matching identity among sequenced clones or in the TAP database. 
Fig. 1. Study sites: samples were collected from different redox depths from sediment cores sampled in April 2006 at three coastal areas of the Baltic Sea. Sampling locations in the Askö area of the Stockholm archipelago: A $\left(58^{\circ} 49^{\prime} \mathrm{N} 17^{\circ} 31^{\prime} \mathrm{E}\right)$, B $\left(58^{\circ} 49^{\prime} \mathrm{N} 17^{\circ} 32^{\prime} \mathrm{E}\right), \mathrm{C}\left(58^{\circ} 49^{\prime} \mathrm{N} 60^{\circ} 29^{\prime} \mathrm{E}\right)$.

Fig. 2. Ordination diagrams from correspondence analysis (CA) of 16S rRNA genes amplified from totally extracted DNA (a) and from BrdU-labeled DNA (b) from TRFLP analysis of vertical sediment profiles of replicate sediments cores collected at three different sampling stations, A, B and C in Askö area (Fig. 1). Three replicate samples per site were analyzed for redox depths $179 \mathrm{mV}$ and $-337 \mathrm{mV}$. Six replicate samples were analyzed from redox depth $-64 \mathrm{mV}$. Eigenvalues for first- and second ordination axes for total DNA extracts and for BrdU-labeled DNA were $83 \%$ and $2 \%$ and $62 \%$ and $2 \%$, respectively.

Fig. 3. Unrooted16S rRNA gene trees based on maximum likelihood analyses representing sequences belonging to A) Gamma-, Alpha-, Beta- and Epsilonproteobacteria, B) Deltaproteobacteria, WS3, SBR1093, Nitrospirae, Firmicutes, Caldithrix_KSB1, TM6, Cyanobacteria and Gemmatimonadetes, C) Actinobacteria, OD2, OP11, Chloroflexi and Chlorobi, D) Acidobacteria, OS-K, OP8, Bacteroidetes, Verrucomicrobia, OP3 and Planctomycetes from BrdU at redox depths $179 \mathrm{mV}$ (blue); $-64 \mathrm{mV}$ (red); $-337 \mathrm{mV}$ (green); from rt-PCR at redox depth $-64 \mathrm{mV}$ (turquoise). Reference sequences (black) are indicated by their Greengenes identity numbers. Sequence numbers are followed by their respective accession numbers in GenBank. The nomenclature suggested by Hugenholtz (DeSantis et al., 2006) was used for taxonomy. One thousand bootstrapped replicate resampling data sets were 
analyzed and the scale bar represents $10 \%$ sequence divergence. Bootstrap values below 500 are not shown.

Fig. 4. Bacterial phyla at the different redox depths according to clone analysis of $16 \mathrm{~S}$ rRNA gene sequences from different depths using BrdU-labeled DNA (BrdU -64 mV; $179 \mathrm{mV} ;-337 \mathrm{mV})$ and cDNA from rt-PCR of RNA (-64 mV).

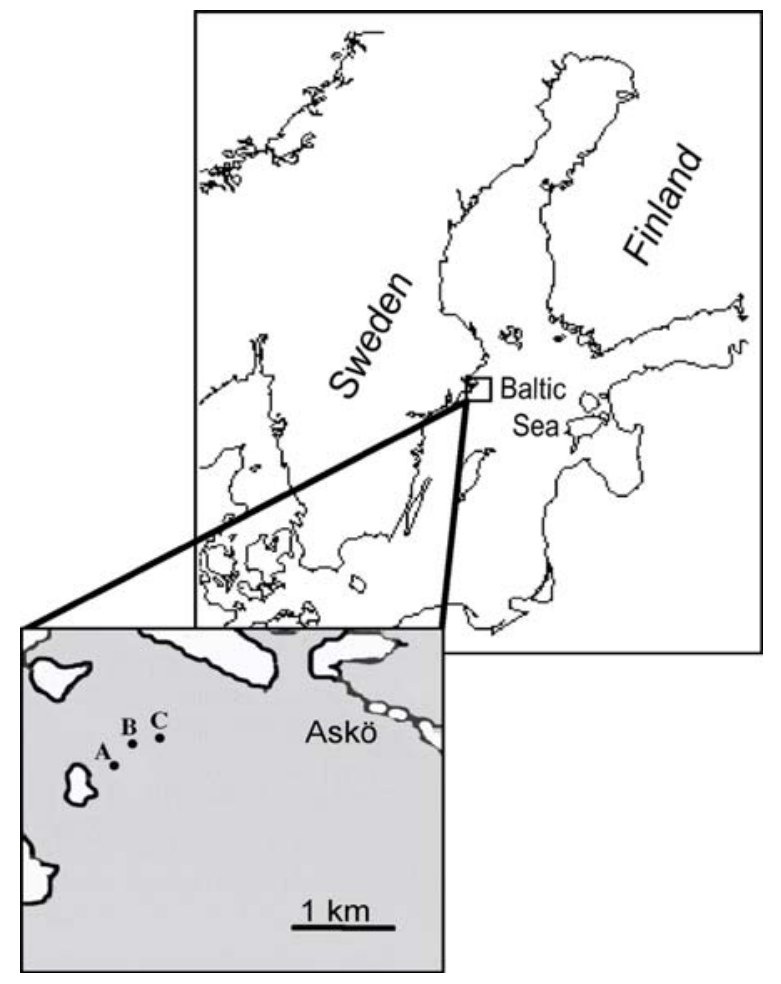

Figure 1 

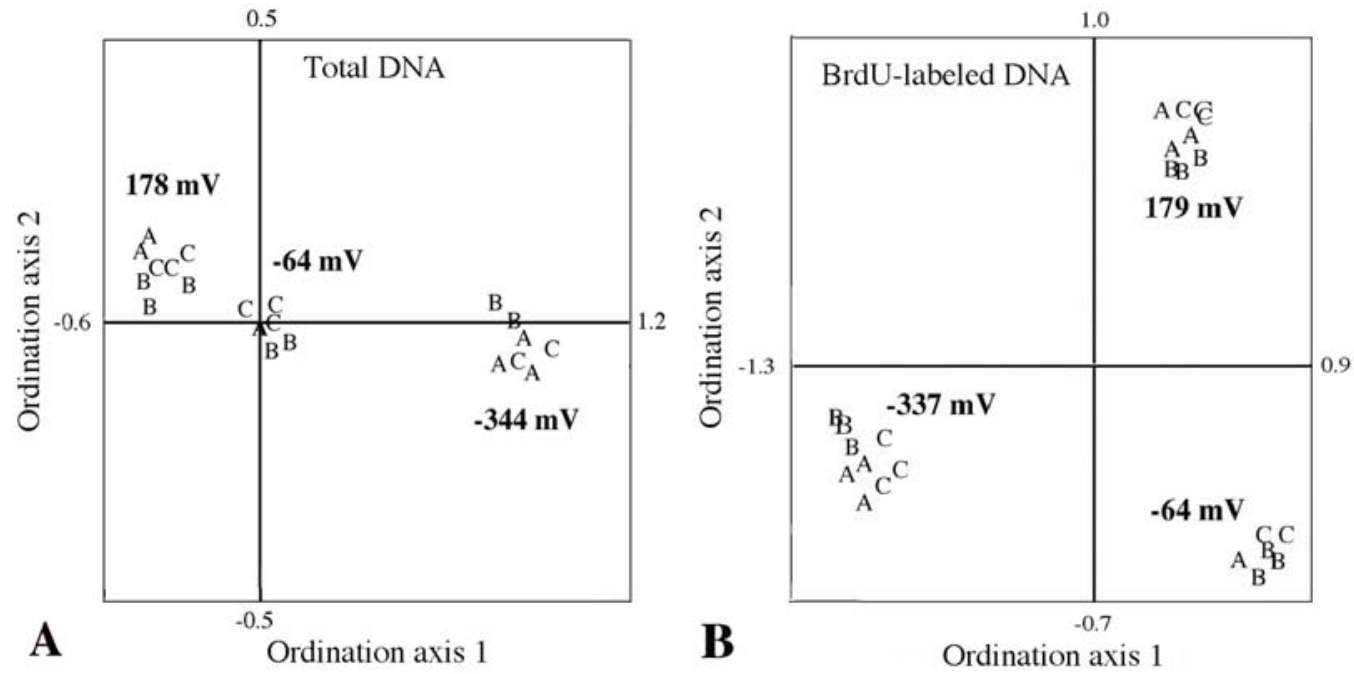

Figure 2 


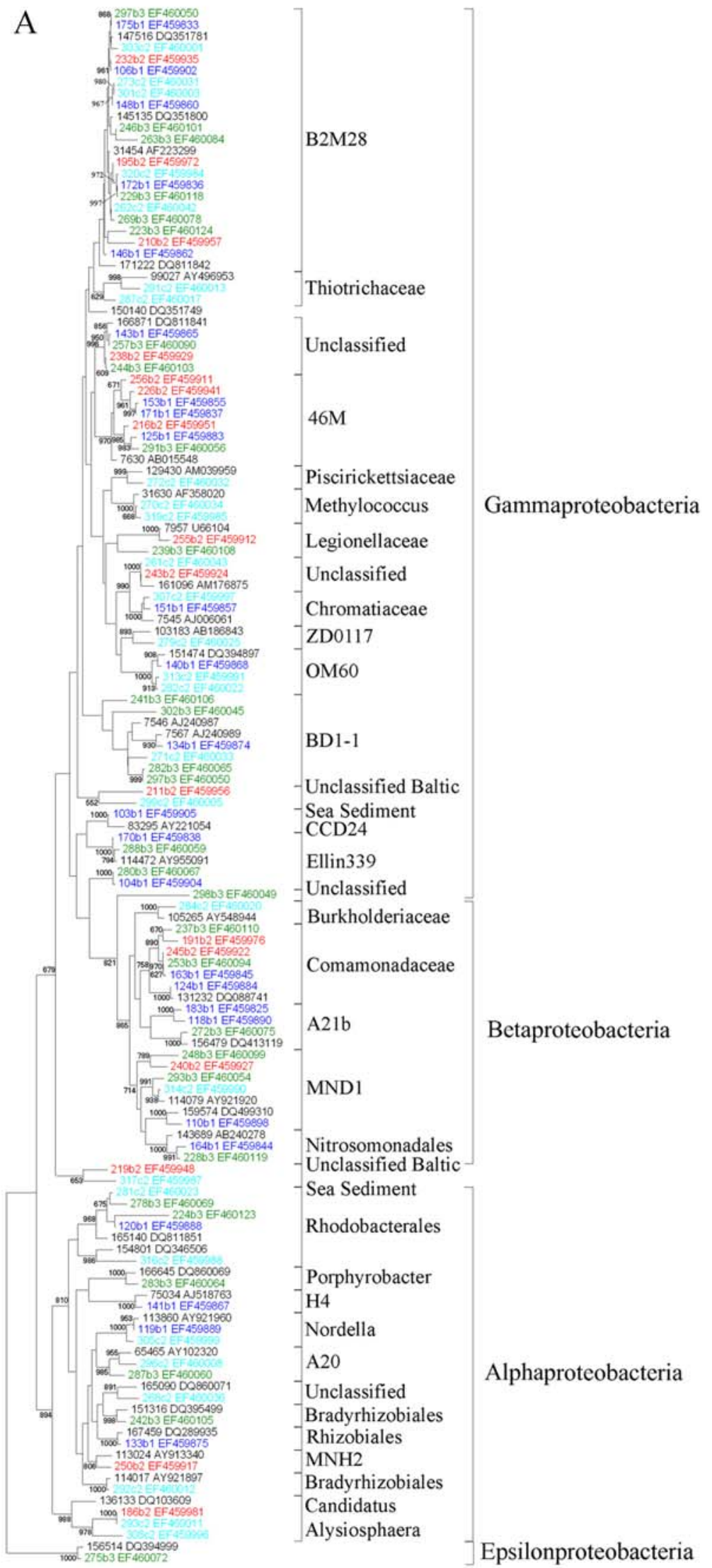

Figure $3 \mathrm{~A}$ 


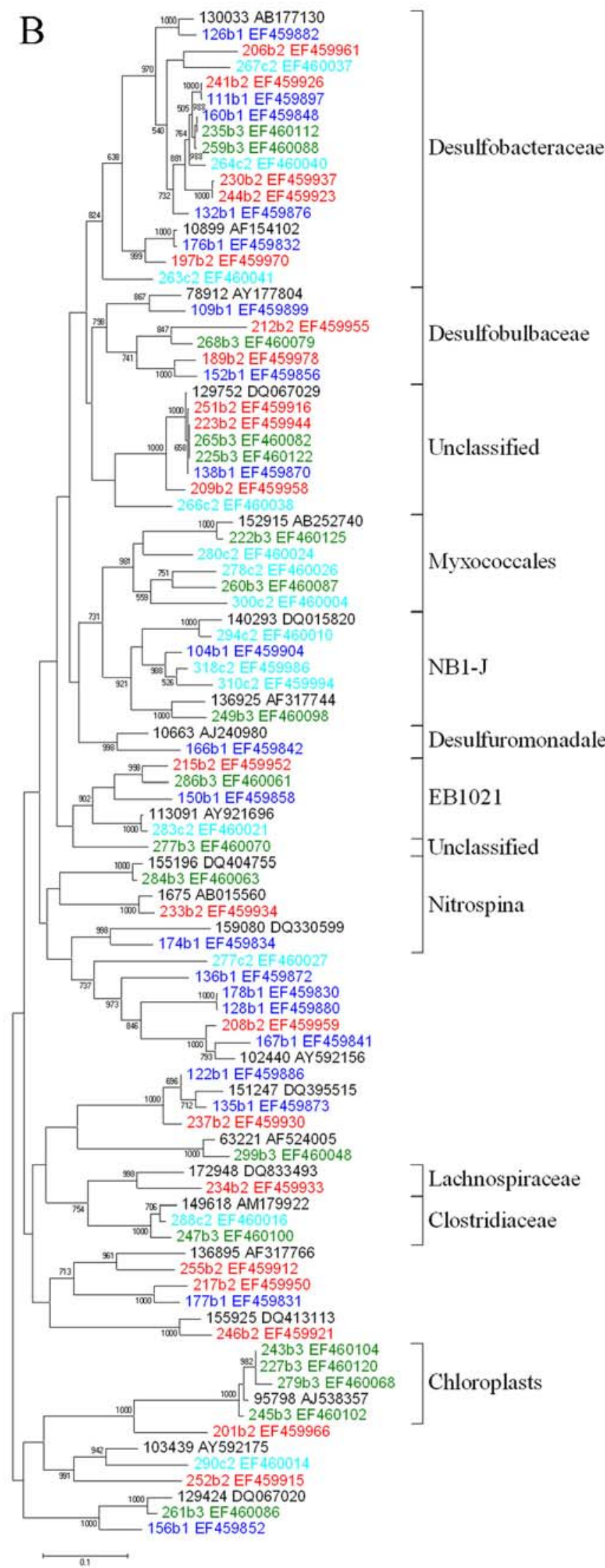

Deltaproteobacteria

WS3

SBR1093

Nitrospirae

Firmicutes

Caldithrix_KSB1

TM6

Cyanobacteria

Unclassified

Gemmatimonadetes

Figure 3B 


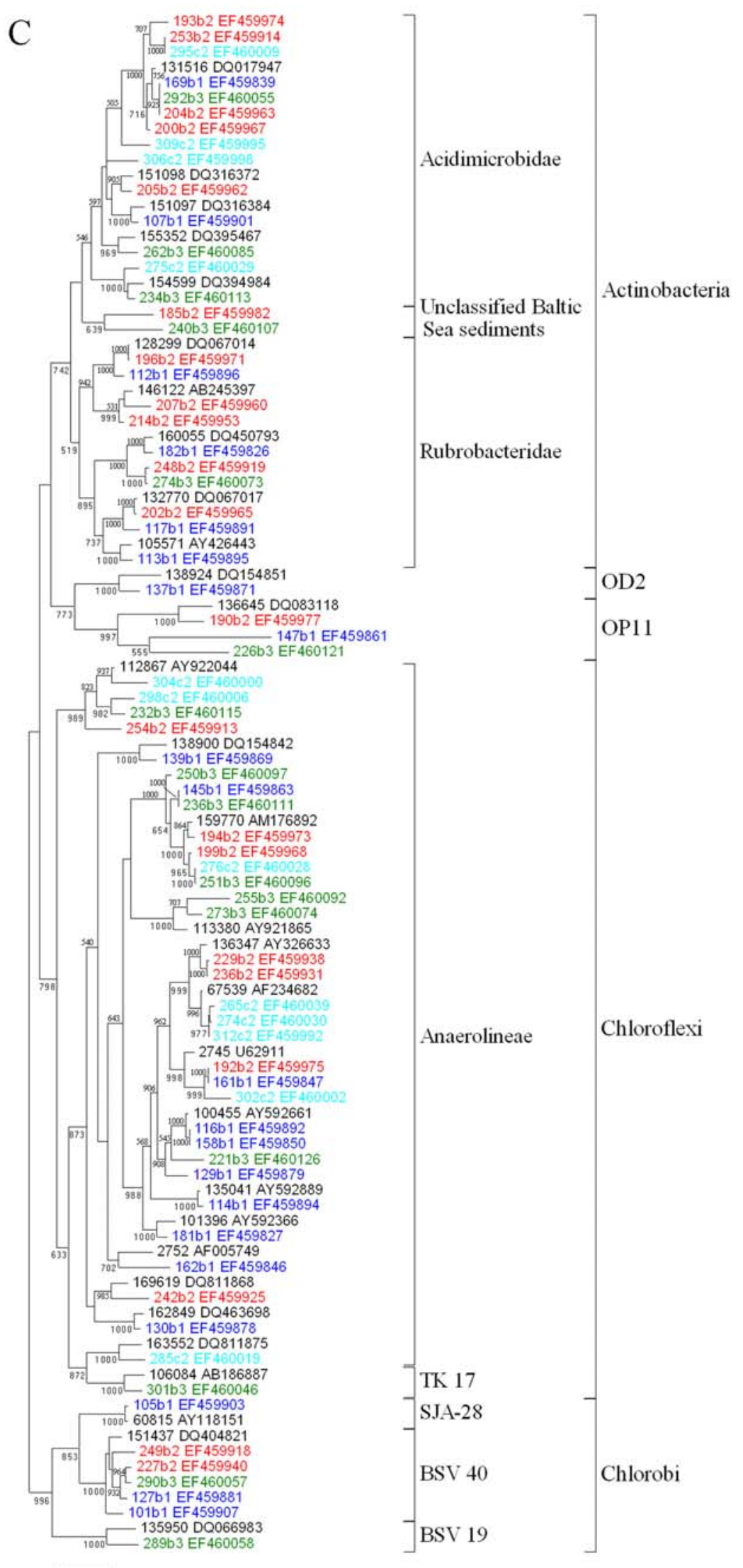

Figure 3C 

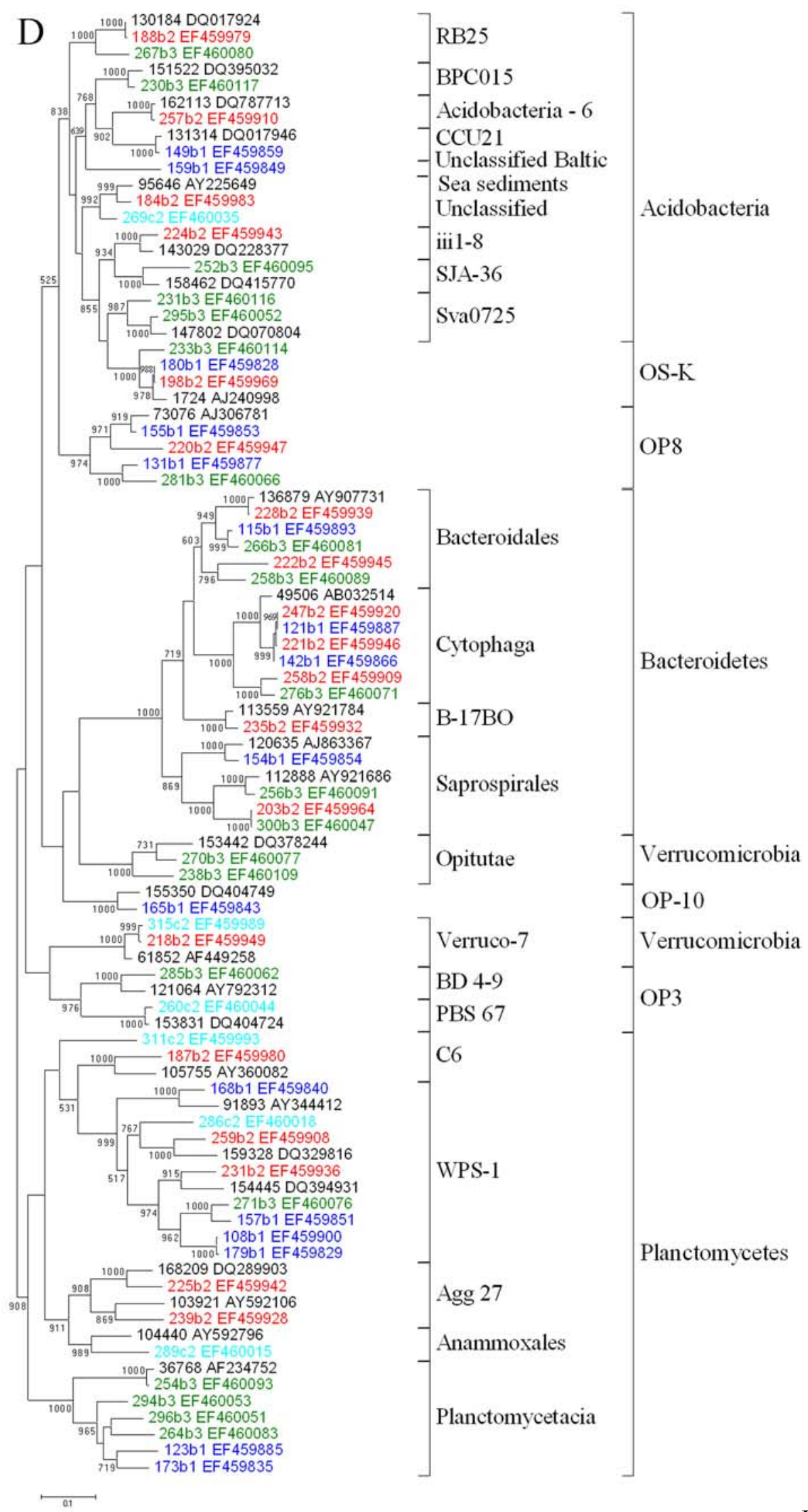

Figure 3D 


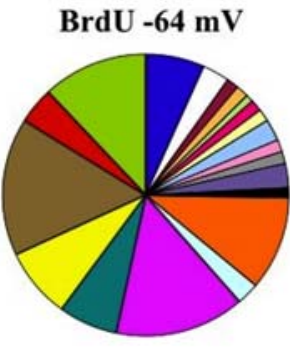

BrdU $179 \mathrm{mV}$

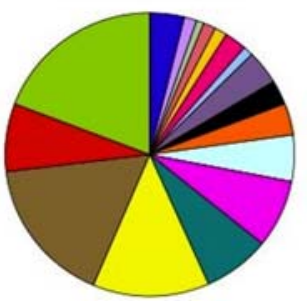

RNA -64 mV

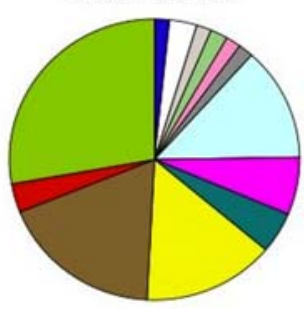

BrdU -337 mV

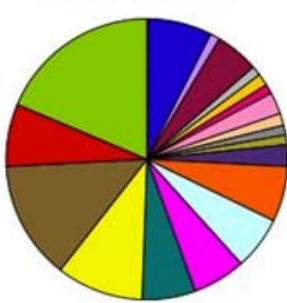

Figure 4 $\square$ Bacteroidetes Actinobacteria

$\square$ Chloroflexi

Planctomycetes

Firmicutes

- Acidobacteria

Unel.OTU_80

Chlorobi

$\square$ Caldithrix_KSB1

$\square$ Verrucomicrobia

口TM6

- Cyanobacteria

$\square$ Uncl. proteobacteria

마

$\square$ Gemmatimonadetes

$\square$ OD2

$\square$ Unclassified

口 OP8

- SBR 1093

Nitrospiriae

Alphaproteobacteria

Deltaproteobacteria

Betaproteobacteria

Epsilonproteobacteria

$\square$ Gammaproteobacteria 